\title{
Shrub expansion in the Arctic may induce large-scale carbon losses due to changes in plant-soil interactions
}

\author{
Thomas C. Parker (D) - Alana M. Thurston - Katrine \\ Raundrup • Jens-Arne Subke • Philip A. Wookey • \\ Iain P. Hartley
}

Received: 5 October 2020 / Accepted: 10 March 2021 / Published online: 21 March 2021

(C) The Author(s) 2021

\begin{abstract}
Background Tall deciduous shrubs are increasing in range, size and cover across much of the Arctic, a process commonly assumed to increase carbon (C) storage. Major advances in remote sensing have increased our ability to monitor changes aboveground, improving quantification and understanding of arctic greening. However, the vast majority of $\mathrm{C}$ in the Arctic is stored in soils, where changes are more uncertain.

Scope We present pilot data to argue that shrub expansion will cause changes in rhizosphere processes, including the development of new mycorrhizal associations that have the potential to promote soil $\mathrm{C}$ losses that substantially exceed $\mathrm{C}$ gains in plant biomass. However, current observations are limited in their spatial extent, and mechanistic understanding is still developing.
\end{abstract}

Responsible Editor: Eric Paterson.

T. C. Parker $(\bowtie) \cdot$ J.-A. Subke · P. A. Wookey

Biological and Environmental Sciences, Faculty of Natural

Sciences, University of Stirling, Stirling FK9 4LA, UK

e-mail: t.c.parker@stir.ac.uk

A. M. Thurston

Bio-Protection Research Centre, Lincoln University,

P.O. Box 85084, 7674 Lincoln, New Zealand

K. Raundrup

Greenland Institute of Natural Resources, 3900 Nuuk, Greenland

I. P. Hartley

Geography, College of Life and Environmental Sciences,

University of Exeter, Exeter EX4 4RJ, UK
Extending measurements across different regions and tundra types would greatly increase our ability to predict the biogeochemical consequences of arctic vegetation change, and we present a simple method that would allow such data to be collected.

Conclusions Shrub expansion in the Arctic could promote substantial soil $\mathrm{C}$ losses that are unlikely to be offset by increases in plant biomass. However, confidence in this prediction is limited by a lack of information on how soil $\mathrm{C}$ stocks vary between contrasting Arctic vegetation communities; this needs to be addressed urgently.

Keywords Shrub expansion - Arctic $\cdot$ Soil . Rhizosphere $\cdot$ Carbon cycle $\cdot$ Climate change

\section{Advances in understanding of above-ground vegetation change in the Arctic}

The arctic tundra stores globally important amounts of carbon (C) and has the potential to strongly regulate feedbacks to climate change (Schuur et al. 2015). Many areas of the tundra are becoming more productive (Epstein et al. 2012), especially in the 'low Arctic' where tall, ectomycorrhizal (ECM) deciduous shrubs are increasing in stature and cover as a result of climate warming (Myers-Smith et al. 2011; Elmendorf et al. 2012a). Furthermore, the forest-tundra ecotone is slowly shifting northward, bringing ECM trees into the tundra (Rees et al. 2020). As tall shrubs and trees expand in range, they are predicted to overgrow large areas of: (1) 
dwarf shrub communities which are comprised of shortstature evergreen and deciduous shrubs that mostly form ericoid mycorrhizal associations (ERM), and (2) sedge tundra which is dominated by non-mycorrhizal (NM) graminoid communities (Tape et al. 2006; Pearson et al. 2013; Mekonnen et al. 2018a). Predicted shifts in plant community composition over the coming century, particularly in the Low Arctic are in the order of hundreds of thousands of $\mathrm{km}^{2}$ (Pearson et al. 2013), therefore the associated ecosystem changes and feedbacks could be at an equally large scale.

The aboveground response of plant communities to warming has been robustly constrained by decades of plot-level measurements (Elmendorf et al. 2012b). In parallel, satellites have documented ecosystem greening (Myneni et al. 1997; Reichle et al. 2018) and significant progress is being made in bridging the scale gaps between plot and satellites, while revealing further nuance with respect to the response of vegetation to extreme events (Myers-Smith et al. 2020). Through progressively more complex syntheses powered by a network of long-term tundra warming experiments (International Tundra Experiment (ITEX); Henry and Molau 1997), researchers have been successful in linking thousands of aboveground measurements of plant traits to environmental changes. This has developed an increasingly pan-Arctic understanding of vegetation dynamics in response to climate and other environmental drivers (Arft et al. 1999; Walker et al. 2006; Elmendorf et al. 2012a, b; Bjorkman et al. 2018).

Aboveground trait data have been key in raising hypotheses as to how plant community change will influence ecosystem processes and C storage (MyersSmith et al. 2019). For example, leaf litter decomposition experiments suggest that the expansion of deciduous shrubs may promote a negative feedback to climate change due to increases in leaf litter production and the fact that their litter decomposes relatively slowly compared to forb, grass and sedge litter, and only slightly faster than litter from dwarf evergreen shrubs (Cornelissen et al. 2007). Aboveground plant traits are also well known to regulate wider ecosystem properties such as soil temperatures (Kropp et al. 2020), through interactions between canopy height and snow trapping in the winter (Sturm et al. 2005), or canopy leaf area and shading in the summer (Blok et al. 2010). Changes in canopy properties could therefore influence permafrost thaw and the exposure of permafrost $\mathrm{C}$ to degradation, depending on the relative strength of summer and winter feedbacks. In their present state, models tend to predict an increase in soil $\mathrm{C}$ in high-latitude ecosystems as a result of increases in $\mathrm{C}$ inputs from greater plant productivity (Qian et al. 2010; Todd-Brown et al. 2013; Mekonnen et al. 2018b). However, the visible aboveground portion of tundra plant biomass is the tip of the $\mathrm{C}$ 'iceberg' (Iversen et al. 2015). Root biomass usually outweighs shoot biomass substantially and is closely linked with the large stores of soil $\mathrm{C}$ which are often concentrated towards the soil surface (Kuhry et al. 2013). It is therefore critical to consider rhizosphere processes when assessing whole ecosystem responses to shrub expansion.

\section{The need for greater understanding of plant-soil interactions}

The C-rich upper soil horizons in the active layer of tundra soils are under a range of different biologicallydriven controls; plant life drives variation in small-scale soil processes that may have an important influence on soil C stocks. Variation in rooting traits such as turnover rate, morphology and mycorrhizal symbiosis (Iversen et al. 2015), root exudation and positive priming (Hartley et al. 2012; Keuper et al. 2020; Street et al. 2020) and associated microbial community structuring (Deslippe et al. 2011; Morgado et al. 2015), have the potential to exert a strong top-down control over patterns of soil C storage in arctic ecosystems. Despite this, soils in the Arctic are often contextualised and studied with broad-scale soil classifications and geomorphological controls in mind (Hugelius et al. 2013). These important syntheses emphasise the total size of the soil $\mathrm{C}$ pool and its potential to contribute to a large climate feedback as the Arctic warms, focusing on the potential for increases in soil heterotrophic activity as permafrost starts to thaw (Kuhry et al. 2013; Schuur et al. 2015). Tundra soils are, though, rarely studied in the context of the current plant community. When the two are measured in parallel it is often part of an experiment designed to test physico-chemical drivers of change, such as temperature (Rinnan et al. 2008; Clemmensen et al. 2012; Sistla et al. 2013; DeMarco et al. 2014), or nutrient availability (Mack et al. 2004), rather than plant community composition as a key biotic driver of soil organic matter dynamics. A major challenge is to understand the degree to which tundra plants control soil C stocks and how this interacts with climate drivers. 
Without detailed studies that take into account both plant community composition and soil, we may miss some of the most immediate and dynamic controls over soil C storage. Equally, while aboveground-only studies are important in their own right, a much more comprehensive understanding of ecosystem dynamics under vegetation change requires similarly robust soil $\mathrm{C}$ measurements in parallel.

There is a small, but growing, body of work that considers $\mathrm{C}$ storage and process rates of plants and soils in the Arctic together. Comparisons between treeline forest and open ericaceous tundra heath (Sjögersten and Wookey 2009; Hartley et al. 2012), or moist acidic tundra (Wilmking et al. 2006), have found that forest soils store less $\mathrm{C}$ than adjacent tundra soils. More recently, researchers found that deciduous shrubdominated plant communities also have the lowest soil $\mathrm{C}$ storage of measured treeless communities, despite having greater leaf area and productivity (Parker et al. 2015, 2020; Sørensen et al. 2018). In each case, these lower $\mathrm{C}$ stocks in the soils more than compensate for the greater plant biomass (Sloan et al. 2013). Here, we present two more datasets from the Low Arctic of Alaska (Fig. 1b) and Southwest Greenland (Fig. 1c), alongside published data from Sweden (Fig. 1a; Parker et al. 2015). These show that coverage of deciduous shrubs (Betula nana and Salix glauca) is not positively correlated with soil $\mathrm{C}$ stock across the three locations, and that shrub cover was in fact negatively related to soil $\mathrm{C}$ stocks in Sweden and Greenland. Furthermore, there was no observable relationship between standing litter stocks and shrub cover, which would be required as a key intermediary (Myers-Smith et al. 2019) if leaf litter inputs were driving soil $\mathrm{C}$ accumulation (Fig. 1b). Taken together, these data force us to acknowledge that we are overlooking key processes in terms of understanding how plant community composition and productivity control soil and ecosystem C storage.

\section{Potential mechanisms explaining differences in soil $C$ between vegetation communities}

One of the most important mechanisms potentially explaining the differences in soil $\mathrm{C}$ storage between plant communities may be related to their dominant mycorrhizal association. ECM fungi are known to have the potential for varying degrees of extracellular hydrolytic and oxidative enzyme expression, depending on the species (Lindahl and Tunlid 2015; Zak et al. 2019; Frey 2019). Restricting delivery of autotrophic $\mathrm{C}$ to ECM communities in a boreal forest has been shown to result in a large reduction of extracellular enzyme production, in particular, Mnperoxidase (Sterkenburg et al. 2018). This enzyme is used by some ECM fungi (in particular Cortinarius spp. ;Bödeker et al. 2014) to decay complex organic matter molecules in order to mineralise $\mathrm{N}$, especially in northern ecosystems with limited mineral $\mathrm{N}$ availability. Indeed, alleviation of $\mathrm{N}$ limitation by experimental fertilisation of boreal (Bödeker et al. 2014) and tundra (Dunleavy and Mack 2021) ecosystems results in reduction of oxidative enzyme production by mycorrhizal fungi. Given the majority of $\mathrm{N}$ in the tundra is bound in organic matter (Shaver et al. 1992), and this would need to be liberated to maintain enhanced tall shrub growth, $\mathrm{N}$ 'mining' in systems that have been colonised by tall ECM-shrubs has the potential to promote substantial soil C losses.

Furthermore, process-based studies indicate that $\mathrm{C}$ inputs from tall-stature shrubs and trees are unlikely to promote soil $\mathrm{C}$ sequestration following colonisation of arctic tundra. We now understand that much of the extra $\mathrm{C}$ fixed by high leaf area shrub communities (Street et al. 2007; Sloan et al. 2013) is rapidly allocated belowground, assimilated by microbial communities (Street et al. 2018), and then respired back to the atmosphere (Sørensen et al. 2018; Parker et al. 2020). As well as the activity of the ECMs themselves, the increase in new $\mathrm{C}$ inputs can promote the activity of saprotrophic microbes (Hicks et al. 2020) which can also stimulate the mineralisation of older soil C (Hartley et al. 2012; Keuper et al. 2020; Hicks et al. 2020; Street et al. 2020). Such positive priming responses, and associated increases in nutrient mineralisation, may further explain the low $\mathrm{C}$ stocks observed under tall-shrub canopies (Wilmking et al. 2006; Parker et al. 2015, 2020; Sørensen et al. 2018). Overall, following ECM colonisation, there appears to be limited potential for sequestration of new $\mathrm{C}$ inputs, but substantial potential for losses, depending on how autotrophic $\mathrm{C}$ is distributed and utilised in the rhizosphere.

ERM fungi are also well known to produce a broad range of extracellular enzymes and have a large capacity for direct organic $\mathrm{N}$ uptake (Smith and Read 2008), but our understanding of their ecology is still largely confined to laboratory studies (Read and Perez-Moreno 2003). However, it may be that they produce 
(a) Abisko

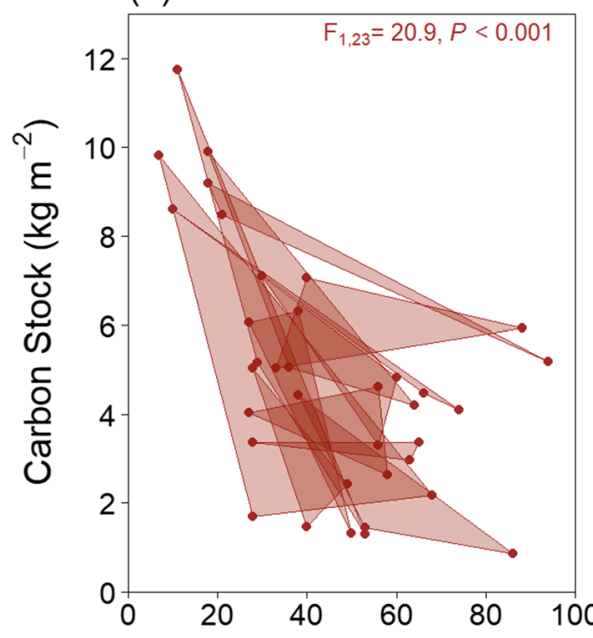

(b) Toolik Lake

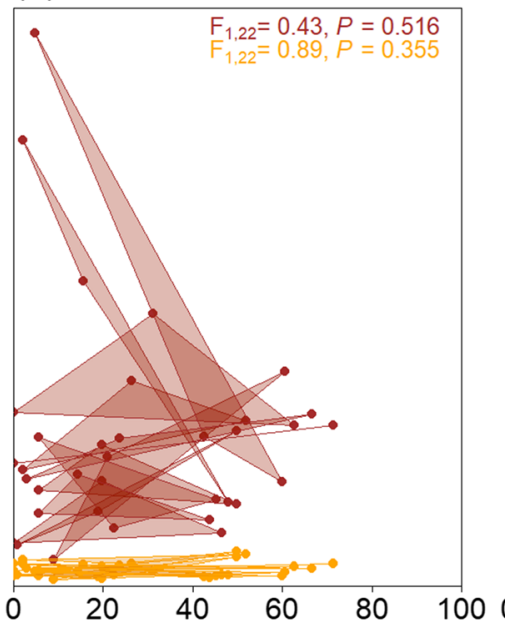

Tall Deciduous Shrub Cover (\%) (c) Kobbefjord

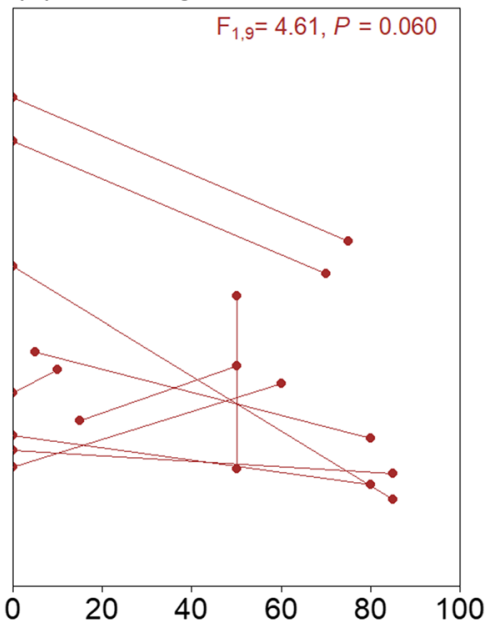

Fig. 1 Organic horizon soil carbon (red) and litter carbon (orange) in relation to varying tall deciduous shrub cover over multiple vegetation transitions at three tundra sites. Connecting lines and shade indicate geographically paired transects with 'low', 'medium' or 'high' shrub cover plots ('low' and 'high' only in (c)). For context, plots with $100 \%$ tall deciduous shrub cover store approximately, $0.6 \mathrm{~kg} \mathrm{~m}^{-2}$ of biomass (not C) in tall shrub biomass (Chen et al. 2009). Statistics refer to results of linear mixed effects models testing the relationship between deciduous shrub cover and $\mathrm{C}$ stocks at each site. A description of methods can be found in Supplemental Information

than under Pinus sylvestris. Given that dwarf Betula spp. (Betula nana L. and Betula glandulosa Michx.) are one of the most important groups contributing to the expansion of deciduous shrubs in the Arctic (Myers-Smith et al. 2011), increases in the abundance of Betula spp. may be particularly important in promoting soil $\mathrm{C}$ losses.

In the data that we have presented, soil $\mathrm{C}$ stocks at Abisko and Kobbefjord were negatively related to shrub cover, but there was no detectable relationship at Toolik Lake (Fig. 1b). This raises an interesting contrast: ericaceous shrubs are less dominant at the Toolik Lake field site, which is moist acidic tundra comprised of a relatively even mix of sedges, mosses, deciduous shrubs and evergreen ericaceous shrubs (Chapin et al. 1995). In contrast, the low stature plots at Abisko and Kobbefjord are strongly dominated by ericaceous evergreen shrubs. The soil organic matter in ERM communities in Abisko are known to contain a high proportion of relatively easily decomposable O-alkyl compound classes (Sjögersten et al. 2003) which likely originated from a fungal necromass source (Clemmensen et al. 2013). Certain ECMs could be well adapted to breaking down fungal necromass which tends to turn over quickly, given an appropriate fungal community (Fernandez et al. 2015), therefore the soil $\mathrm{C}$ in ericaceous soils could 
be particularly vulnerable to C loss following ECM shrub encroachment.

\section{The relative importance of above- versus belowground changes}

Deciduous shrub expansion and colonisation of lower stature tundra communities will result in an increase in aboveground biomass (Epstein et al. 2012), but the changes in belowground traits (as described above), including mycorrhizal status (Clemmensen et al. 2015), belowground biomass turnover rate (Sloan et al. 2013) and positive priming (Hartley et al. 2012; Street et al. 2020) may lead to an overall loss of $\mathrm{C}$ at the ecosystem level, at least when the community being colonised has a substantial component of ericaceous shrubs. Critically, the potential losses of soil $\mathrm{C}$ may be an order of magnitude greater than the potential gains in plant biomass. This is because, with much greater below-ground $\mathrm{C}$ stocks, even small pro- portional losses in soil C can outweigh large proportional gains in aboveground biomass. Furthermore, there is an upper limit to the size that tall shrubs can grow before becoming limited by their own growth form at around $1 \mathrm{~kg} \mathrm{C} \mathrm{m}$, based on remote sensing and ground-truthing of the most productive tall shrub tundra (Berner et al. 2018). Net ecosystem losses of C shortly after shrub colonisation does, however, assume that soil losses take place on a similar timescale to the gains in plant biomass. This may not be entirely the case, aboveground $\mathrm{C}$ gains and soil $\mathrm{C}$ losses will likely occur on different temporal scales, which studies addressing relatively recent shifts in vegetation distribution have to take account of. The recent evaluation of the consequences of tree planting on organic soils demonstrated that substantial C losses from soils can take place on decadal timescales (Friggens et al. 2020), similar to rates of tree biomass growth, but these dynamics could differ in the Arctic and Subarctic. We argue that, in the tundra, it is likely that variation in mycorrhizal traits and subsequent decom-

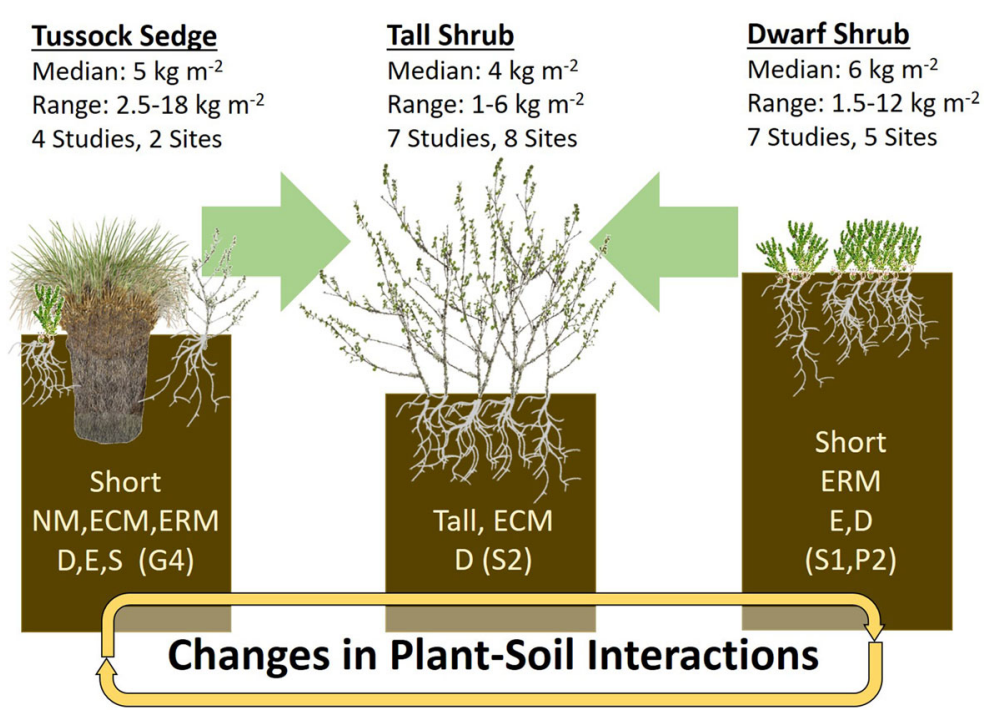

Fig. 2 Proposed consequences of soil C stocks following changes between three important tundra plant communities due to climate change. Relative size of brown boxes indicates best estimates of organic horizon C stocks (median of literature values, including the present study). Text in each box represents relative canopy height (tall or short), dominant mycorrhizal symbiosis (ectomycorrhizal, ECM; ericoid mycorrhizal, ERM; non-mycorrhizal, NM), (co)dominant plant functional type (deciduous shrub, D; evergreen shrub, E; sedge, S) and closest Circumpolar Arctic Vegetation Map (CAVM) classification (Walker et al. 2005). Green arrows indicate modelled vegetation transitions due to climate change (Pearson et al. 2013). The number of studies (to our knowledge) that measure organic horizon $\mathrm{C}$ stocks in each plant community and the number of sites these studies cover are listed (see Table S1 for literature values and paper references). Potentially important changes in plant-soil interactions with changes in vegetation include a likely increase in root litter turnover rates, shifts in dominant mycorrhizal symbiosis and associated microbial community composition change, and increases in rhizosphere priming rates. Tussock sedge diagram credit: N.R.Fuller, SayoStudio 
position in the rhizosphere will play a greater role in controlling patterns of soil $\mathrm{C}$ storage than variation in aboveground traits and leaf litter decomposition (Cornelissen et al. 2007). Furthermore, the evidence suggests that the large-scale expansion of tall deciduous ECM shrubs that is predicted over the coming century (Pearson et al. 2013) may promote a loss of soil $\mathrm{C}$, especially when the tundra that is being colonised is currently ERM-dominated (Fig. 2).

\section{Widespread soil sampling alongside vegetation sampling and analysis}

To determine the consequences of changes in vegetation community distribution for $\mathrm{C}$ storage, we need to improve our ability to link aboveground plant traits with belowground plant traits and soil C storage. With ongoing monitoring of aboveground vegetation change, it may then become possible to improve predictions of the consequences for soil and ecosystem $\mathrm{C}$ stocks. We argue, however, that the scientific community is not yet in a position to do this.

There are timely and important initiatives taking place to increase measurements of, and synthesise knowledge on, belowground plant traits in the Arctic (Iversen et al. 2015). However, this still lags far behind the volume of data that is collected aboveground. Furthermore, even basic information on how much soil $\mathrm{C}$ is stored beneath different plant communities is very limited (Fig. 2, Table S1). Plant and soil responses to climate change are often studied independently, and there is a scarcity of studies that pair measurements of their stocks and processes at comparable scales. There is therefore the clear and pressing need for coordinated above- and belowground sampling, of the kind presented in Fig. 1, across the tundra biome. As we list in Fig. 2, there are only a handful of studies that explicitly measure soil $\mathrm{C}$ stocks in the organic horizon and these estimates only apply to a small number of sites. The Abisko and Toolik Lake sites (Fig. 1a and b) are two of the most studied sites in the Arctic for climate change research (Metcalfe et al. 2018), and increasing the diversity and geographical range of sites is essential to test the broader-scale applicability of above-belowground linkages. To this end, we present a simple protocol (Supplementary Information) for measuring plant cover, litter and organic horizon soil $\mathrm{C}$ stocks in parallel.

\section{Conclusion}

Major advances have been made in quantifying and understanding the changes in plant community composition that are taking place in the Arctic. However, we argue that predicting the consequences for biogeochemical feedbacks to climate change is currently constrained by the low number of combined studies of above- and belowground plant traits and soil C stocks. Such studies are urgently required to identify and quantify key relationships between plant communities and soil C. Critically, the data that we present here challenge the assumption that increasing plant productivity will promote greater ecosystem $\mathrm{C}$ storage and emphasise the need to make similar measurements across contrasting tundra ecosystems and plant communities. Such efforts offer the opportunity to move beyond plant- or soil-centric viewpoints, and to generate whole-ecosystem understanding of controls over $\mathrm{C}$ storage in arctic ecosystems.

Supplementary Information The online version contains supplementary material available at https://doi.org/10.1007/s11104021-04919-8

Acknowledgements This work was funded by the Natural Environment Research Council (NERC) grant numbers NE/ P002722/1 and NE/P002722/2 to PAW, JA-S and IPH. TCP and AMT accessed Toolik Field Station with assistance from student project funding by NSF/PLR 1418010, NSF/PLR 1417645 and NSF/PLR 1417763; we warmly thank Ned Fetcher, Jianwu Tang and Michael Moody for providing this opportunity. The research leading to the results at Kobbefjord has received funding from the European Union's Horizon 2020 project INTERACT, under grant agreement No 730938. We thank staff of the Abisko Naturvetenskapliga Station and Toolik Lake Field Station for their assistance and logistical support. Data from the Greenland Ecosystem Monitoring Programme were provided by Asiaq - Greenland Survey, Nuuk, Greenland. We thank Karina Clemmensen for helpful insights during the development of this opinion paper, and François-Xavier Joly for internally reviewing the manuscript. Our thanks go to the three anonymous reviewers whose comments significantly improved the manuscript.

Author contributions All authors contributed to study design at different sites. TCP, AMT and KR collected the data at Abisko, Toolik Lake and Kobbefjord respectively. TCP led the writing of the manuscript, with contributions from all the authors.

\section{Data availability Data are available in File ESM2}

Open Access This article is licensed under a Creative Commons Attribution 4.0 International License, which permits use, sharing, adaptation, distribution and reproduction in any medium or format, 
as long as you give appropriate credit to the original author(s) and the source, provide a link to the Creative Commons licence, and indicate if changes were made. The images or other third party material in this article are included in the article's Creative Commons licence, unless indicated otherwise in a credit line to the material. If material is not included in the article's Creative Commons licence and your intended use is not permitted by statutory regulation or exceeds the permitted use, you will need to obtain permission directly from the copyright holder. To view a copy of this licence, visit http://creativecommons.org/licenses/by/4.0/.

Open Access This article is licensed under a Creative Commons Attribution 4.0 International License, which permits use, sharing, adaptation, distribution and reproduction in any medium or format, as long as you give appropriate credit to the original author(s) and the source, provide a link to the Creative Commons licence, and indicate if changes were made. The images or other third party material in this article are included in the article's Creative Commons licence, unless indicated otherwise in a credit line to the material. If material is not included in the article's Creative Commons licence and your intended use is not permitted by statutory regulation or exceeds the permitted use, you will need to obtain permission directly from the copyright holder. To view a copy of this licence, visit http://creativecommons.org/licenses/by/4.0/.

\section{References}

Arft AM, Walker MD, Gurevitch J et al (1999) Responses of tundra plants to experimental warming: Meta-analysis of the international tundra experiment. Ecol Monogr 69:491511. https://doi.org/10.1890/0012-9615(1999)069[0491 :rotpte]2.0.co;2

Berner LT, Jantz P, Tape KD, Goetz SJ (2018) Tundra plant above-ground biomass and shrub dominance mapped across the North Slope of Alaska. Environ Res Lett 13:35002. https://doi.org/10.1088/1748-9326/aaaa9a

Bjorkman AD, Myers-Smith IH, Elmendorf SC et al (2018) Plant functional trait change across a warming tundra biome. Nature 562:57-62. https://doi.org/10.1038/s41586-0180563-7

Blok D, Heijmans MMPD, Schaepman-Strub G et al (2010) Shrub expansion may reduce summer permafrost thaw in Siberian tundra. Glob Chang Biol 16:1296-1305. https://doi. org/10.1111/j.1365-2486.2009.02110.x

Bödeker ITM, Clemmensen KE, de Boer W et al (2014) Ectomycorrhizal Cortinarius species participate in enzymatic oxidation of humus in northern forest ecosystems. New Phytol 203:245-256. https://doi.org/10.1111/nph.12791

Chapin FS, Shaver GR, Giblin AE et al (1995) Responses of arctic tundra to experimental and observed changes in climate. Ecology 76:694-711

Chen W, Li J, Zhang Y et al (2009) Relating biomass and leaf area index to non-destructive measurements in order to monitor changes in arctic vegetation. Arctic 62:281-294

Clemmensen KE, Michelsen A, Jonasson S, Shaver GR (2012) Increased abundance after ectomycorrhizal fungal fertilization and warming of two arctic tundra ecosystems. New Phytol 171:391-404. https://doi.org/10.1111/j.14698137.2006.01778.x

Clemmensen KE, Bahr A, Ovaskainen O et al (2013) Roots and associated fungi drive long-term carbon sequestration in boreal forest. Science 339:1615-1618. https://doi.org/10.1126 /science. 1231923

Clemmensen KE, Finlay RD, Dahlberg A et al (2015) Carbon sequestration is related to mycorrhizal fungal community shifts during long-term succession in boreal forests. New Phytol 205:1525-1526. https://doi.org/10.1111/nph.13208

Cornelissen JHC, van Bodegom PM, Aerts R et al (2007) Global negative vegetation feedback to climate warming responses of leaf litter decomposition rates in cold biomes. Ecol Lett 10: 619-627. https://doi.org/10.1111/j.1461-0248.2007.01051.x

DeMarco J, Mack MC, Bret-Harte MS et al (2014) Long-term experimental warming and nutrient additions increase productivity in tall deciduous shrub tundra. Ecosphere 5. https://doi.org/10.1890/es13-00281.1

Deslippe JR, Hartmann M, Mohn WW, Simard SW (2011) Longterm experimental manipulation of climate alters the ectomycorrhizal community of Betula nana in Arctic tundra. Glob Chang Biol 17:1625-1636. https://doi.org/10.1111 j.1365-2486.2010.02318.x

Dunleavy HR, Mack MC (2021) Long-term experimental warming and fertilization have opposing effects on ectomycorrhizal root enzyme activity and fungal community composition in Arctic tundra. Soil Biol Biochem 154: 108151. https://doi.org/10.1016/j.soilbio.2021.108151

Elmendorf SC, Henry GHR, Hollister RD et al (2012a) Plot-scale evidence of tundra vegetation change and links to recent summer warming. Nat Clim Chang 2:453-457. https://doi. org/10.1038/nclimate1465

Elmendorf SC, Henry GHR, Hollister RD et al (2012b) Global assessment of experimental climate warming on tundra vegetation: heterogeneity over space and time. Ecol Lett 15:164 175. https://doi.org/10.1111/j.1461-0248.2011.01716.x

Epstein HE, Raynolds MK, Walker DA et al (2012) Dynamics of aboveground phytomass of the circumpolar Arctic tundra during the past three decades. Environ Res Lett 7:015506. https://doi.org/10.1088/1748-9326/7/1/015506

Fernandez CW, Langley JA, Chapman S et al (2015) The decomposition of ectomycorrhizal fungal necromass. Soil Biol Biochem. https://doi.org/10.1016/j.soilbio.2015.10.017

Frey SD (2019) Mycorrhizal fungi as mediators of soil organic matter dynamics. Annu Rev Ecol Evol Syst 50:237-259. https://doi.org/10.1146/annurev-ecolsys-110617-062331

Friggens NL, Hester AJ, Mitchell RJ et al (2020) Tree planting in organic soils does not result in net carbon sequestration on decadal timescales. Glob Chang Biol. https://doi.org/10.1111 /gcb.15229

Hartley IP, Garnett MH, Sommerkorn M et al (2012) A potential loss of carbon associated with greater plant growth in the European Arctic. Nat Clim Chang 2:875-879. https://doi. org/10.1038/nclimate 1575

Henry GHR, Molau U (1997) Tundra plants and climate change: the International Tundra Experiment (ITEX). Glob Chang Biol 3:1-9. https://doi.org/10.1111/j.1365-2486.1997. gcb132.x

Hicks LC, Leizeaga A, Rousk K et al (2020) Simulated rhizosphere deposits induce microbial $\mathrm{N}$-mining that may 
accelerate shrubification in the subarctic. Ecology :e03094. https://doi.org/10.1002/ecy.3094

Hugelius G, Tarnocai C, Broll G et al (2013) The northern circumpolar soil carbon database: Spatially distributed datasets of soil coverage and soil carbon storage in the northern permafrost regions. Earth Syst Sci Data 5:3-13. https://doi. org/10.5194/essd-5-3-2013

Iversen CM, Sloan VL, Sullivan PF et al (2015) Tansley review The unseen iceberg: plant roots in arctic tundra. New Phytol 205:34-58

Keuper F, Wild B, Kummu M et al (2020) Carbon loss from northern circumpolar permafrost soils amplified by rhizosphere priming. Nat Geosci. https://doi.org/10.1038/s41561020-0607-0

Kropp H, Loranty MM, Natali SM et al (2020) Shallow soils are warmer under trees and tall shrubs across Arctic and Boreal ecosystems. Environ Res Lett 16:15001. https://doi. org/10.1088/1748-9326/abc994

Kuhry P, Grosse G, Harden JW et al (2013) Characterisation of the permafrost carbon pool. Permafr Periglac Process 24:146155. https://doi.org/10.1002/ppp.1782

Lindahl BD, Tunlid A (2015) Ectomycorrhizal fungi - potential organic matter decomposers, yet not saprotrophs. New Phytol 205:1443-1447. https://doi.org/10.1111/nph.13201

Mack MC, Schuur EAG, Bret-Harte MS et al (2004) Ecosystem carbon storage in arctic tundra reduced by long-term nutrient fertilization. Nature 431:440-443. https://doi.org/10.1038 /nature 02887

Mekonnen ZA, Riley WJ, Grant RF (2018) Accelerated nutrient cycling and increased light competition will lead to $21 \mathrm{st}$ century shrub expansion in North American Arctic Tundra. J Geophys Res Biogeosci 123:1683-1701. https://doi. org/10.1029/2017JG004319

Mekonnen ZA, Riley WJ, Grant RF (2018b) 21st century tundra shrubification could enhance net carbon uptake of North America Arctic tundra under an RCP8.5 climate trajectory. Environ Res Lett 13:54029. https://doi.org/10.1088/17489326/aabf28

Metcalfe DB, Hermans TDG, Ahlstrand J et al (2018) Patchy field sampling biases understanding of climate change impacts across the Arctic. Nat Ecol Evol 2:1443-1448. https://doi. org/10.1038/s41559-018-0612-5

Morgado LN, Semenova TA, Welker JM et al (2015) Summer temperature increase has distinct effects on the ectomycorrhizal fungal communities of moist tussock and dry tundra in Arctic Alaska. Glob Chang Biol 21:959-972. https://doi.org/10.1111/gcb.12716

Myers-Smith IH, Forbes BC, Wilmking M et al (2011) Shrub expansion in tundra ecosystems: dynamics, impacts and research priorities. Environ Res Lett 6:045509. https://doi. org/10.1088/1748-9326/6/4/045509

Myers-Smith IH, Thomas HJD, Bjorkman AD (2019) Plant traits inform predictions of tundra responses to global change. New Phytol 221:1742-1748. https://doi.org/10.1111/nph.15592

Myers-Smith IH, Kerby JT, Phoenix GK et al (2020) Complexity revealed in the greening of the Arctic. Nat Clim Chang 10: 106-117. https://doi.org/10.1038/s41558-019-0688-1

Myneni RB, Keeling CD, Tucker CJ et al (1997) Increased plant growth in the northern high latitudes from 1981 to 1991. Nature 386:698-702. https://doi.org/10.1038/386698a0
Parker TC, Subke J-A, Wookey PA (2015) Rapid carbon turnover beneath shrub and tree vegetation is associated with low soil carbon stocks at a subarctic treeline. Glob Chang Biol 21: 2070-2081. https://doi.org/10.1111/gcb.12793

Parker TC, Clemmensen KE, Friggens NL et al (2020) Rhizosphere allocation by canopy-forming species dominates soil $\mathrm{CO} 2$ efflux in a subarctic landscape. New Phytol 227:1818-1830. https://doi.org/10.1111/nph.16573

Pearson RG, Phillips SJ, Loranty MM et al (2013) Shifts in Arctic vegetation and associated feedbacks under climate change. Nat Clim Chang 3:673-677. https://doi.org/10.1038 /nclimate 1858

Qian H, Joseph R, Zeng N (2010) Enhanced terrestrial carbon uptake in the Northern High Latitudes in the 21st century from the Coupled Carbon Cycle Climate Model Intercomparison Project model projections. Glob Chang Biol 16:641-656. https://doi.org/10.1111/j.13652486.2009.01989.x

Read DJ, Perez-Moreno J (2003) Mycorrhizas and nutrient cycling in ecosystems - a journey towards relevance? New Phytol 157:475-492. https://doi.org/10.1046/j.14698137.2003.00704.x

Rees G, Hofgaard A, Boudreau S et al (2020) Is subarctic forest advance able to keep pace with climate change? Glob Chang Biol. https://doi.org/10.1111/gcb.15113

Reichle LM, Epstein HE, Bhatt US et al (2018) spatial heterogeneity of the temporal dynamics of Arctic tundra vegetation. Geophys Res Lett 45:9206-9215. https://doi.org/10.1029 /2018GL078820

Rinnan R, Michelsen A, Jonasson S (2008) Effects of litter addition and warming on soil carbon, nutrient pools and microbial communities in a subarctic heath ecosystem. Appl Soil Ecol 39:271-281. https://doi.org/10.1016/j.apsoil.2007.12.014

Schuur EAG, McGuire AD, Schädel C et al (2015) Climate change and the permafrost carbon feedback. Nature 520:171

Shaver GR, Billings WD, Chapin FS et al (1992) Global change and the carbon balance of arctic ecosystems. Bioscience 42: 433-441. https://doi.org/10.2307/1311862

Sistla SA, Moore JC, Simpson RT et al (2013) Long-term warming restructures Arctic tundra without changing net soil carbon storage. Nature 497:615-615+. https://doi. org/10.1038/nature12129

Sjögersten S, Wookey PA (2009) The impact of climate change on ecosystem carbon dynamics at the Scandinavian Mountain birch forest-tundra heath ecotone. Ambio 38:2-10

Sjögersten S, Turner BL, Mahieu N et al (2003) Soil organic matter biochemistry and potential susceptibility to climatic change across the forest-tundra ecotone in the Fennoscandian mountains. Glob Chang Biol 9:759-772. https://doi. org/10.1046/j.1365-2486.2003.00598.x

Sloan VL, Fletcher BJ, Press MC et al (2013) Leaf and fine root carbon stocks and turnover are coupled across Arctic ecosystems. Glob Chang Biol 19:3668-3676. https://doi. org/10.1111/gcb.12322

Smith SE, Read D (2008) 11 - Ericoid mycorrhizas. In: Read SES (ed) Mycorrhizal symbiosis, 3rd edn. Academic, London, pp 389-418

Sørensen MV, Strimbeck R, Nystuen KO et al (2018) Draining the pool? Carbon storage and fluxes in three alpine plant communities. Ecosystems 21:316-330. https://doi.org/10.1007 /s10021-017-0158-4 
Sterkenburg E, Clemmensen KE, Ekblad A et al (2018) Contrasting effects of ectomycorrhizal fungi on early and late stage decomposition in a boreal forest. ISME J 12:21872197. https://doi.org/10.1038/s41396-018-0181-2

Street LE, Shaver GR, Williams M, Van Wijk MT (2007) What is the relationship between changes in canopy leaf area and changes in photosynthetic CO 2 flux in arctic ecosystems? J Ecol 95:139-150. https://doi.org/10.1111/j.13652745.2006.01187.x

Street LE, Subke J-A, Baxter R et al (2018) Ecosystem carbon dynamics differ between tundra shrub types in the western Canadian Arctic. Environ Res Lett 13:84014. https://doi. org/10.1088/1748-9326/aad363

Street LE, Garnett MH, Subke J-A et al (2020) Plant carbon allocation drives turnover of old soil organic matter in permafrost tundra soils. Glob Chang Biol. https://doi. org/10.1111/gcb.15134

Sturm M, Schimel J, Michaelson G et al (2005) Winter biological processes could help convert arctic tundra to shrubland. Bioscience 55:17-26. https://doi.org/10.1641/0006-3568 (2005)055[0017:WBPCHC]2.0.CO;2

Tape K, Sturm M, Racine C (2006) The evidence for shrub expansion in Northern Alaska and the Pan-Arctic. Glob Chang Biol 12:686-702. https://doi.org/10.1111/j.13652486.2006.01128.x
Todd-Brown KEO, Randerson JT, Hopkins F et al (2013) Changes in soil organic carbon storage predicted by Earth system models during the 21 st century. Biogeosciences Discuss 10:18969-19004. https://doi.org/10.5194/bgd-1018969-2013

Walker DA, Raynolds MK, Daniëls FJA et al (2005) The circumpolar Arctic vegetation map. J Veg Sci 16:267-282. https://doi.org/10.1111/j.1654-1103.2005.tb02365.x

Walker MD, Wahren CH, Hollister RD et al (2006) Plant community responses to experimental warming across the tundra biome. Proc Natl Acad Sci U S A 103:1342-1346. https://doi.org/10.1073/pnas.0503198103

Wilmking M, Harden J, Tape K (2006) Effect of tree line advance on carbon storage in NW Alaska. J Geophys Res 111: G02023. https://doi.org/10.1029/2005jg000074

Zak DR, Pellitier PT, Argiroff WA et al (2019) Exploring the role of ectomycorrhizal fungi in soil carbon dynamics. New Phytol 223:33-39. https://doi.org/10.1111/nph.15679

Publisher's note Springer Nature remains neutral with regard to jurisdictional claims in published maps and institutional affiliations. 